\title{
Pre-basic seed potato (Solanum tuberosum L.) production using temporary immersion bioreactors
}

\author{
Producción de semilla pre-básica de papa (Solanum tuberosum L.) mediante biorreactores de \\ inmersión temporal
}

\author{
Tapia, M.de L.*1, Arbizu, C. ${ }^{* 2}$, Beraún, F. ${ }^{3}$, Lorenzo, J. ${ }^{4}$, Escalona, M. ${ }^{5}$ \\ *Corresponding author: ltapia@lamolina.edu.pe / carbizu@lamolina.edu.pe
}

\begin{abstract}
Potato is an important food and cash crop in Perú. Its production is limited due to seed quality, and other biotic and abiotic factors. Here we explore a new alternative for potato pre-basic seed production named temporary immersion bioreactor (TIB). Potato microtubers production using TIB comprises two phases: multiplication and microtuberization. During the multiplication phase, we used 50 segments of four nodes from a semi-solid medium with an immersion and frequency time of five minutes and three hours, respectively. In addition, a photoperiod of 16 hours of light and eight hours of darkness during 28 days were employed. For the microtuberization phase and under darkness conditions during 60 days, we used $80 \mathrm{~g} / \mathrm{l}$ of sucrose and $30 \mathrm{ml} /$ explant as a volume for the medium. Then, it was possible to obtain five, six, and 2.5 microtubers per explant of potato varieties "Canchan INIA", "Capiro", and "Papa 3", respectively.
\end{abstract}

Keywords: Microtubers, temporary immersion bioreactor, pre-basic seed, microtuberization.

\section{Resumen}

La papa es un alimento importante y cultivo de alta importancia económica en Perú. Su producción es limitada debido a la calidad de las semillas y otros factores bióticos y abióticos. Aquí exploramos una nueva alternativa para la producción de semilla pre-básica de papa llamada biorreactor de inmersión temporal (BIT). La producción de microtubérculos de papa utilizando BIT comprende dos fases: multiplicación y microtuberización. Durante la fase de multiplicación, se utilizaron 50 segmentos de cuatro nudos de un medio semisólido con un tiempo de inmersión y frecuencia de cinco minutos y tres horas, respectivamente. Además, se empleó un fotoperiodo de 16 horas de luz y ocho horas de oscuridad durante 28 días. Para la fase de microtuberización y en condiciones de oscuridad durante 60 días, se utilizaron $80 \mathrm{~g} / 1$ de sacarosa y $30 \mathrm{ml} /$ explante como volúmen para el medio. Luego fue posible obtener cinco, seis y 2.5 microtubérculos por explante de las variedades de papa "Canchan INIA", "Capiro" y "Papa 3", respectivamente.

Palabras clave: Microtuberculos, biorreactor de inmersión temporal, semilla prebásica, microtuberización

\section{Introduction}

Micropropagation is a widely used technique to obtain plants free of diseases that may be used for the production of minitubers and microtubers throughout the year, becoming the first generation of pre-basic seed (Ranalli 2007). The production of potato microtubers represents a potentially novel method for seed production compared to some limitations present with the use of minitubers, which are difficult to store, delicate, difficult to handle and require an additional acclimatization process (Coleman et al. 2001).

In some potato varieties, the use of nodal segments with two nodes (4 buds) as an explant produced in vitro seedlings with greater vigor compared to the use of nodal segments with a node (Venkatasalam et al. 2012). Larger microtubers are sowed directly into the field. On the other hand, in vitro plants that are obtained from minitubers require acclimatization (Donnely et al. 2003), resulting in a not very economical method. Radouani and Lauer (2015) compared yields of tubers produced from microtubers and minitubers of two potato varieties "Nicola" and "Russet Burbank". Microtubers had a small weight of 0.2-1.5 g, medium weight of more than 1.5 to $3 \mathrm{~g}$, and large ones greater than $3 \mathrm{~g}$. Small minitubers weighed 15-20 g, the medium ones more than 20 to $40 \mathrm{~g}$, and the big ones greater than $40 \mathrm{~g}$. Both varieties produced more tubers from microtubers than from minitubers, 1,033,333 vs

\footnotetext{
${ }^{1}$ Instituto de Biotecnología-Cultivo de Tejidos, Facultad de Agronomía, Universidad Nacional Agraria La Molina, Av. La Molina s/n, Lima 12, Perú. ${ }^{2}$ Instituto de Biotecnología-Genómica y Bioinformática, Facultad de Agronomía, Universidad Nacional Agraria La Molina, Av. La Molina s/n, Lima 12, Perú.

${ }_{3}^{3}$ Departamento de Contabilidad, Facultad de Ciencias Contables, Universidad Nacional del Callao, Av. Juan Pablo II 306, Callao 2, Perú..

${ }^{4}$ Laboratory for Plant Breeding, Centro de Bioplantas, Universidad de Ciego de Ávila, Carretera Morón Km 9 11/2, Ciego de Ávila, Cuba. ${ }^{5}$ Laboratory for Plant Cell and Tissue Culture, Centro de Bioplantas, Universidad de Ciego de Ávila, Carretera Morón Km 9 1/2, Ciego de Ávila, Cuba.
} 
568,750 tubers/ha for "Nicola" and 605,417 vs 482,291 tubers/ha for "Russet Burbank", respectively. In addition, large mini and microtubers had the highest yield with a total of 49 and $40 \mathrm{~T} / \mathrm{ha}$, respectively. The physiologically older microtubers were more prolific than the younger ones; this was particularly found for late cultivars (Ranalli et al. 1994). They found that the yield of potato obtained from microtubers had lower yields compared to minitubers and conventional seed. On the other hand, it was observed that microtubers had longer storage ability (7 months) and also better performance than those with shorter storage time (3 months) (Désiré et al. 1995). Direct planting in the microtuber field can affect the growth and development of the plant. Greater numbers of tubers per plant were recorded in plants from physiologically older microtubers.

Potato cultivation represents $10 \%$ of the Peruvian agricultural gross domestic product, and it is cultivated in 19 out of the 24 departments of Perú. However, potato farmers use only about $0.2 \%$ (1,145 tons) of certified seed (INEI, 2012). Therefore, the present study aims to compare the production of microtubers of three potato varieties "Canchan INIA", "Capiro" and "Papa 3" using temporary immersion bioreactors.

The temporary inversion system consisted of two 4 L polypropylene containers, silicone hoses, 0.2 Mn hydrophobic filters, electrovalves and an air compressor; one container is used for the explants and the other container is used for the culture medium; both bottles are connected through hoses, the frequency and time of investment is controlled through an automated system

\section{Materials and Methods}

In vitro potato plants (Solanum tuberosum L.) of three potato varieties "Canchan INIA", "Capiro" and "Papa 3" were used. These three potato varieties were acquired from the International Potato Center (CIP for its acronym in Spanish) germplasm bank which were obtained from the cultivation of meristems seeded in a starting medium composed of MS salt (Murashige and Skoog 1962). Tests that were carried out at CIP were: NASH for the detection of Potato spindle tuber viroid (PSTVd), serological test of ELISA, and test of indicator plant. All of these tests were performed over a period of 2 months.

The basal composition of the Murashigue \& Skoog medium (1962) modified by Espinoza (1991) was used

The modification consisted of the use of ammonium nitrate $(1,750 \mathrm{mgl})$, potassium nitrate $(2,000 \mathrm{mg} / \mathrm{L})$, calcium chloride $(450 \mathrm{mg} / \mathrm{L})$ and phosphate $(175 \mathrm{mg} / \mathrm{L})$ thiamin $(0.4 \mathrm{mg} / \mathrm{L})$ glycine $(2.0 \mathrm{mg} / \mathrm{L})$, nicotimic acid $(0.5$ $\mathrm{mg} / \mathrm{L})$, pyridoxine $(0.5 \mathrm{mg} / \mathrm{L})$ calcium pantothenate $(2$ $\mathrm{mg} / \mathrm{L})$ and arginine $(4 \mathrm{mg} / \mathrm{L})$.

The $\mathrm{pH}$ of the culture medium was adjusted to 5.8 before steam sterilization in the autoclave. The time and frequency of immersion were 4 minutes every three hours.

The culture conditions were 16 hours of light, and 8 hours of darkness; fluorescent white light lamps were used to guarantee a flow of photosynthetic photons of $40 \mu \mathrm{mol} \cdot \mathrm{m}^{-2} \cdot \mathrm{s}^{-1}$. We used a relative humidity between $60-70 \%$ during the phase of multiplication, and in the microtuberization phase the sucrose concentration was increased. Incubation conditions were performed under dark conditions.

For inoculation in the temporary immersion bioreactors (TIB), segments with 2 nodes (4 axillary buds) were used from a third subculture in semi-solid medium. Polypropylene containers of 4-liter capacity were used. The culture medium was the MS (Murashige and Skoog 1962) modified by Espinoza et al. (1986).

For the TIB multiplication phase, 50 explants/TIB, 15 $\mathrm{ml}$ medium/explant volume, time and immersion frequency of 4 minutes every 3 hours for 28 days were used with a photoperiod of 16 hours of light and 8 hours of darkness. After this time, the microtuberization was induced in the TIB; the flask containing the culture medium was replaced by another with fresh medium of the same composition but, supplemented with $80 \mathrm{~g} / \mathrm{l}$ of sucrose without renewal of the medium. The volume of the medium was 1.5 liters (30 $\mathrm{ml} /$ explant), and the immersion time and frequency were 4 minutes every 3 hours (8F/day), culture time of 60 days under darkness at a temperature of 22 celsius. Three TIBs were used per treatment (Fig. 1).

In order to harvest the microtubers, the container was opened and carefully separated from the plant and root residues. Then, microtubers were rinsed with tap water to remove the culture medium, and were placed in trays on filter paper to remove moisture. The total number of microtubers per bioreactor was evaluated, as well as the number of microtubers per shoot. In addition, fresh mass (g) was evaluated using a Sartorius analytical weight.

\section{Statistical Analyses}

Statistical analyses were performed using the SPSS software version 11.5. The analyses for the different variables were performed through a one-way ANOVA, bifactorial ANOVA or a t-test, as parametric analyses. One-way ANOVA and bifactorial ANOVA were followed by a Tukey test. Previously, normal distribution and homogeneity of variance were also demonstrated according to the Kolmogorov-Smirnov and Levene tests, respectively. The data of discrete variables were transformed with the equation $y^{\prime}=(y+0.5) \times 0.5$, and the percentage variables according to the equation $y^{\prime}=2 \operatorname{arcosen}((y / 100) \times 0.5)$.

\section{Results}

\section{Protocol of microtuberización for obtaining pre-basic seed in three potato varieties.}

Figure 2 shows the results of the protocol used in the present study for the formation of microtubers in three potato varieties. No significant differences were found in the number of microtubers per bioreactor between the "Canchan INIA" and "Capiro" varieties but with "Papa 3" variety. Varieties "Canchan INIA" and "Capiro" produced 

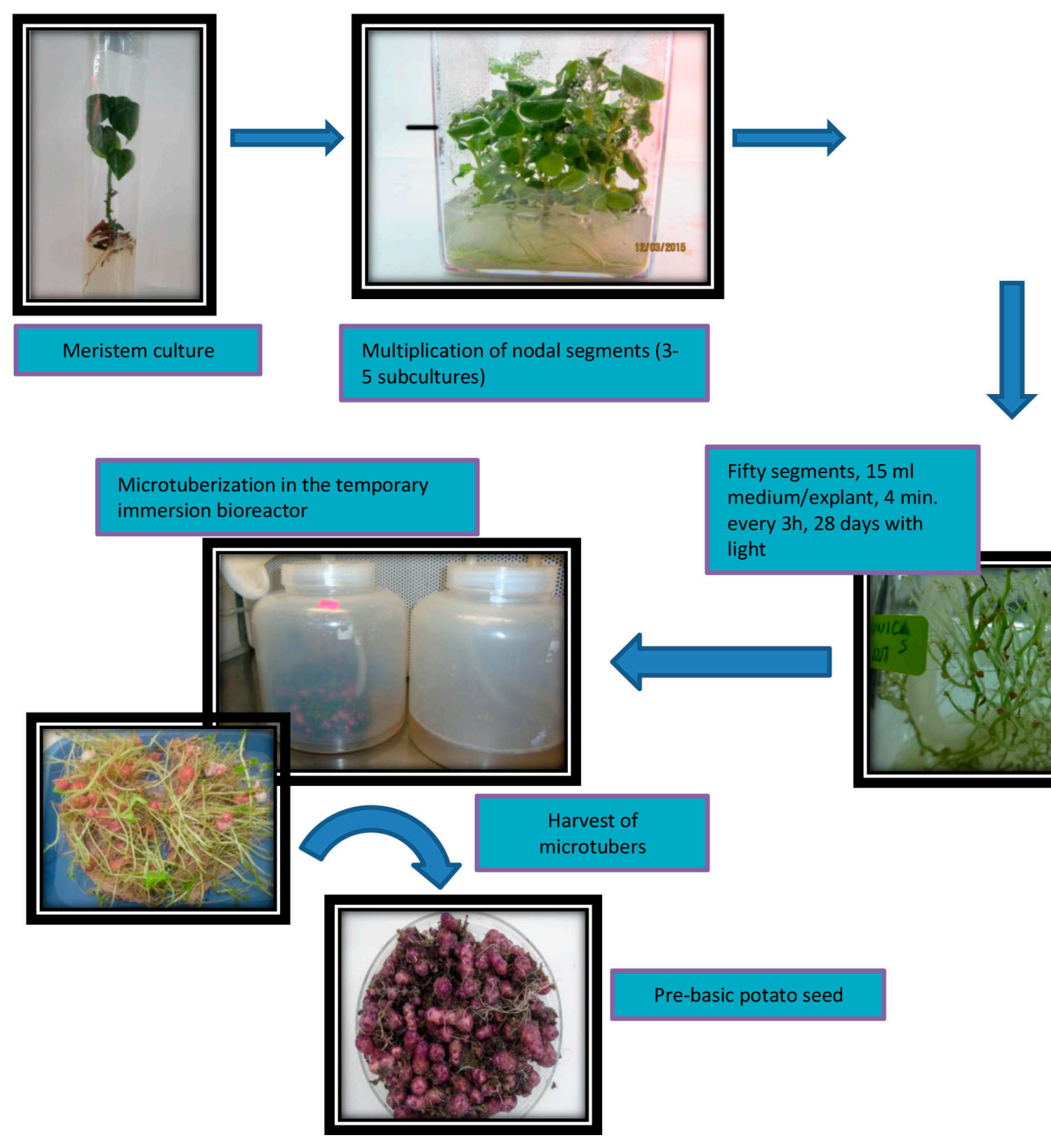

Figure 1. Protocol for the production of potato microtubers using temporary immersion bioreactors (TIB)

a total of 250 and 270 microtubers, respectively. On the other hand, "Papa 3" produced only 100 microtubers (Fig. 2A). As for the number of microtubers, the "Canchan INIA" and "Capiro" potato varieties produced a significant average of 5 and 6 microtubers per explant, respectively. Variety "Papa 3" had a lower average (2.5 microtubers per explant) (Fig. 2B). No statistical difference was observed between the three potato varieties for fresh mass of the microtubers (Fig. 2C).

Potato variety "Papa 3" produced microtubers of 1.2 $\mathrm{cm}$, resulting significantly different compared to the other two varieties $(1 \mathrm{~cm})$ (Fig. 2D). By analyzing the quality of the microtubers that were formed in the bioreactor and calculating the percentage of microtubers (pre-basic seed) of the three potato varieties with suitable characteristics for direct seeding in the field (greater than $0.5 \mathrm{~g}$ ), we found significant differences between the three potato varieties. The percentage of microtubers of variety "Papa3" was significantly higher (90\%) while varieties "Canchan INIA" and "Capiro" averaged 50 and 36 percent, respectively (Fig. 3).

\section{Discussion}

The dependence of potato genotype for the formation of microtubers is well documented. Gopal et al. (1998) evaluated the formation of microtubers in semi-solid medium of 22 potato genotypes (Solanum tuberosum L.) under six in vitro culture conditions. Cultures in short photoperiod $\left(10 \mathrm{~h}, 6-12 \mu \mathrm{mol} . \mathrm{m}^{-2} \cdot \mathrm{s}^{-1}\right)$ and low temperatures (day: $20^{\circ} \mathrm{C}$ and night: $18^{\circ} \mathrm{C}$ ) had higher yield $(225 \mathrm{mg} /$ plant) and higher number of microtubers (2/plants) than those maintained under long-day conditions (16 h, 38- 


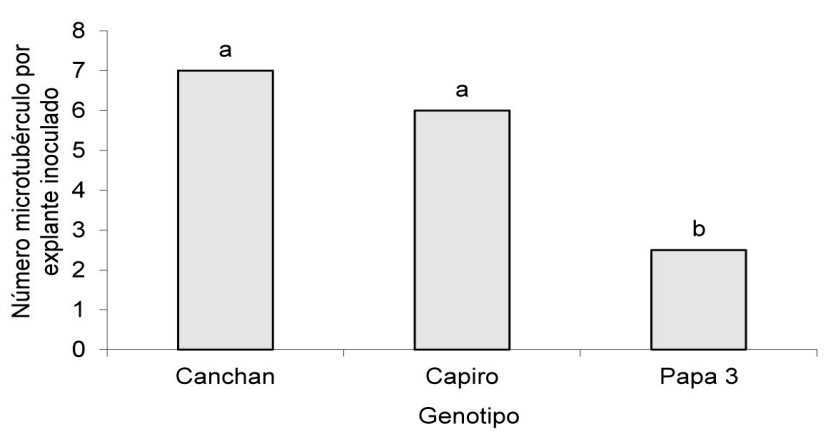

A Media general $=4.27$ ET general $=1.02$

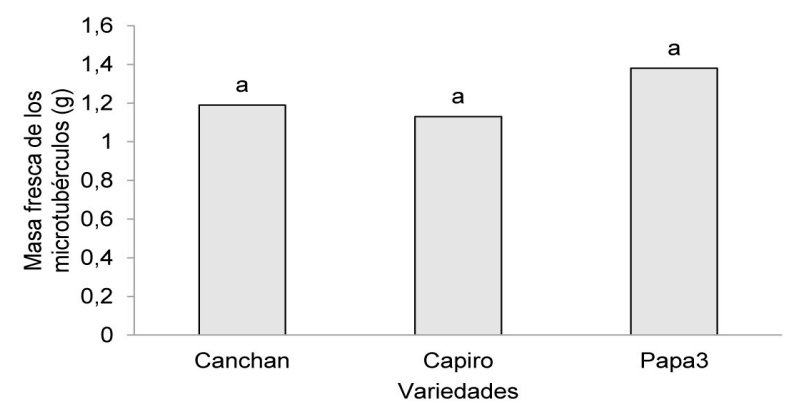

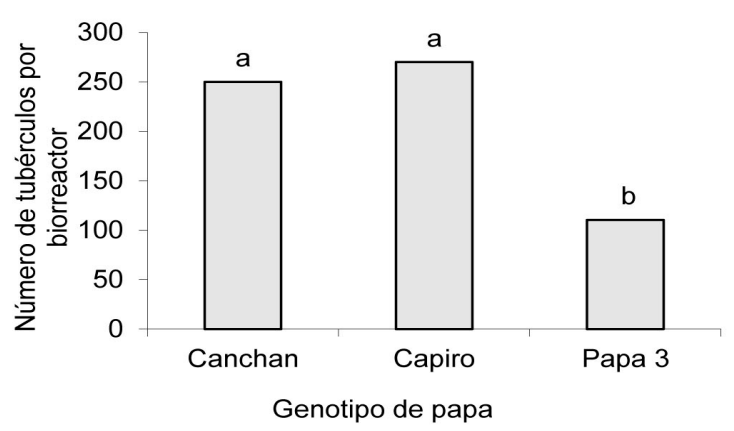

B Media general $=213.44$ ET general $=52.3$

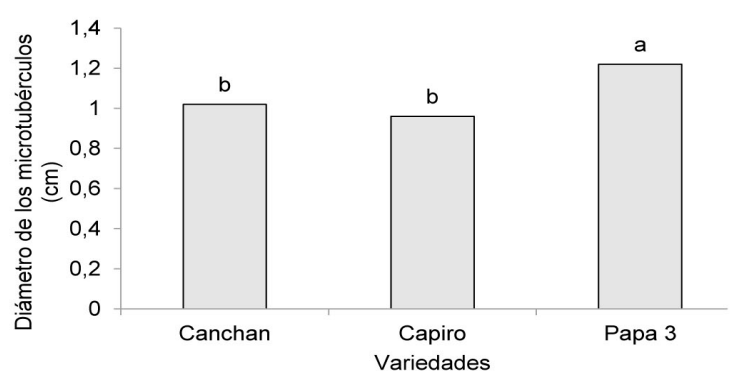

Figure 2. Pre-basic seed in the number of microtubers per bioreactor (A), number of microtubules per explant (B), fresh mass of microtubers (C), and diameter of the microtubers (D). In each figure, means with equal letters do not have statistically significant differences (monofactorial ANOVA, Tukey $\mathrm{p}>0.05$ ). For statistical processing, the number of microtubers was transformed according to $\mathrm{y}=(\mathrm{y}+0.5) \times 0.5$. Data represent the mean of three BIT / treatment.

$50 \mu \mathrm{mol} . \mathrm{m}^{-2} . \mathrm{s}^{-1}$ ) combined with high temperatures (day: $28^{\circ} \mathrm{C}$ and night: $25^{\circ} \mathrm{C}$ ) which yielded $207 \mathrm{mg} /$ plant, and the number of microtubers was $0.9 /$ plants. The mean of the 12 genotypes that tuberized in all treatments varied in the following values, yield of microtubers was 207-644 mg/ plant), number of microtubers was 0.91-2.05, fresh mass of microtubers ranged from 114 to $263 \mathrm{mg}$, and number of eyes was 3.48-5.96. The interaction genotype by culture conditions was significant indicating the importance of developing specific protocols specific for each genotype to maximize microtuberization.

Temporal immersion bioreactors are also reported on differences in the performance of microtubers associated with the genotype. Kämäräinen-Karppinen et al (2010) evaluated four genotypes and found that the number of microtubers/bioreactors ranged from 30 in "Asterix" to 75 in "Velox". The latter cultivar yielded a greater number of microtubers with crop capacity than the rest. Teisson and Alvard (1999) also found differences in the microtuberization of three potato cultivars in liquid medium using temporary immersion. The number of microtubers/ bioreactor was in the range of 48 in the "Desirée", 52 and 68 for "Bintje" and "Ostara", respectively. Variety "Ostara" achieved a greater number of microtubers/internode (2.3) and fresh mass varied from $20.6 \mathrm{~g}$ for "Bintje", $35.5 \mathrm{~g}$ for "Ostara" and $39.9 \mathrm{~g}$ in "Desirée". The microtubers of the latter cultivar were very large, some of them with mass of $6 \mathrm{~g}$. In addition, Jiménez et al. (1999) evaluated the microtuberization of two cultivars using TIB and the number of microtubers/single node was 3.1 and 2.8 for "Desirée" and "Atlantic", respectively.

The validation of the proposed protocol here for three potato varieties showed a different behavior in the number of microtubers/bioreactor and number of microtubers/ explant. For both parameters, "Papa 3" had the lowest response level (100 microtubers/TIB and 2 microtubers/ explant). Regarding fresh mass of the microtubers, there were no differences between the three potato varieties. This may have been influenced by the favorable cultivation conditions and nutrient level that is achieved in the TIB. However, microtubers of "Papa 3" had a larger diameter influenced perhaps by lower number of microtubers. Also, $90 \%$ of microtubers of this variety had a mass between 0.5 $3.0 \mathrm{~g}$ and, were therefore suitable for direct seeding in the field. The response to microtuberization of seven potato cultivars of different genetic origin and maturity group was investigated under different conditions of photoperiod and intensities of light in a system free of plant growth regulators. Multivariate analysis showed that the genotype was the factor that most affected the variable response in 
A

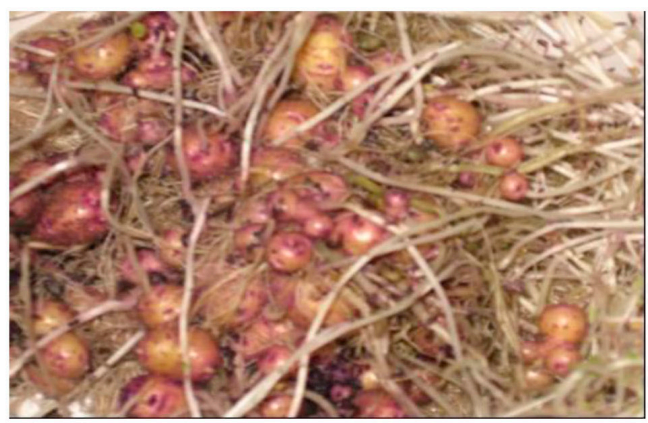

B

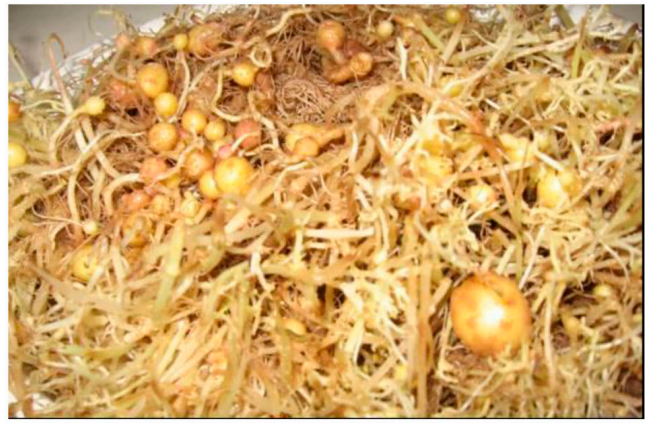

C

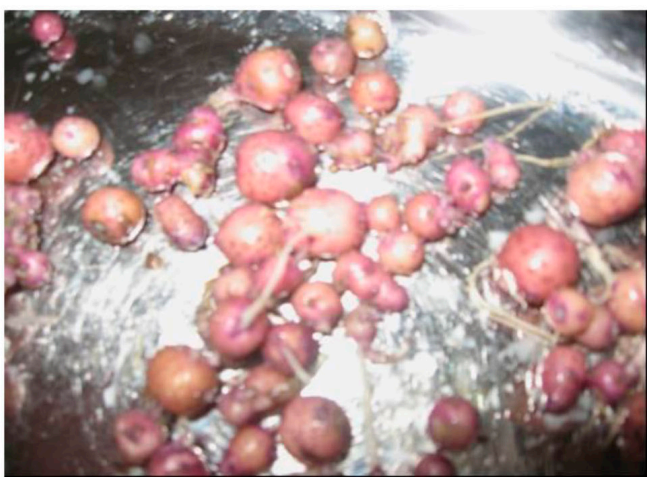

Figure 3. Sixty-day old microtubers of potatoes of the following three varieties used in the present study, "Canchan INIA" (A), "Capiro" (B) and "Papa 3" (C).

microtuberization, indicating that the genetic origin of the clone plays a basic role in tuberization under in vitro conditions (Dobranszki et al. 2008).

\section{Conclusions}

Response of "Canchan INIA", "Capiro" and "Papa 3" potato varieties was compared to the protocol for microtuberization of potato in the TIB that includes two phases, one of multiplication and growth of plants in vitro, and another one of formation of microtubers in the bioreactor. The evaluation of the microtubers/explant is different for each variety, "Canchan INIA" (5), "Capiro" (6), "Papa 3" (2.5). We conclude that there are differences due to the genetics of each variety.

Pre-basic potato seed was obtained for the three Peruvian commercial varieties using temporary immersion bioreactors, demonstrating that microtubers can be used as planting material for direct sowing in the field. Yields were heavily influenced by the potato variety.

\section{References}

Coleman W.K., Donnelly, D.J. and Coleman S.E. (2001). Potato microtubers as research tools. A Review. American Journal of Potato Research 78(1): 47-55. DOI: $10.1007 / \mathrm{BF} 02874824$

Désiré, S., Couillerot, J.P. and Vasseur. J. (1995). Dormancy and sprouting of in vitro potato (Solanum tuberosum L.) microtubers: Effects of sucrose concentration from tuberization medium, storage period at $4{ }^{\circ} \mathrm{C}$ and gibberellic acid treatment. Acta Botanica Gallica 142: 371-378.

Dobranski, J., Magyar-Tabori, K. and Hudak. H. (2008). In vitro tuberization in hormone-free systems on solidified medium and dormancy of potato microtubers. London: Global Science Books.

Donnelly, D.J., Coleman, W.K. and Coleman. S.E. (2003). Potato microtuber production and performance. A review. American Journal Potato Research 80(2): 103115. https://doi.org/10.1007/BF02870209

Espinoza, N.O., Estrada, R., Silva-Rodríguez, D., Tovar, P., Lizzaraga, R., and Dodds. J.H. (1986). The potato: A model crop plant for tissue culture. Outlook on Agriculture 15(1): 21-26. https://doi. org/10.1177/003072708601500104

Gopal, J., Minocha, J.L. and Dhaliwal H.S. (1998). Microtuberization in potato (Solanum tuberosum L.). Plant Cell Report 17(10): 794-798. https://doi. org/10.1007/s002990050485

Instituto Nacional de Estadística e Informática (INEI). (2012). IV Censo Nacional Agropecuario (CNA). Available in: http://proyectos. inei.gob.pe/web/Documentos Publicos/ ResultadosFinalesIVCENAGRO.pdf [2017, august 24]

Jiménez, E., Pérez, N., de Feria, M., Barbón, R., Capote, A., Chávez, M., Quiala, E. and Pérez. J.C. (1999). Improved production of potato microtubers using a temporary immersion system. Plant Cell, Tissue and Organ Culture. 59(1): 19-23. https://doi. org/10.1023/A:1006312029055

Kämäräinen-Karppinen, T., Virtanen, E., Rokka, V.M. and Pirttilä A.M. (2010). Novel bioreactor technology for mass propagation of potato microtubers. Plant Cell, Tissue and Organ Culture 101(2:245-249. DOI: 10.1007/s11240-010-9679-7

Murashige, T., and Skoog, F. (1962). A revised medium for rapid growth and bioassay with tobacco tissue cultures. Physiología Plantarum 15(3): 473-497. https://doi. org/10.1111/j.1399-3054.1962.tb08052.x

Radouani, A, and Lauer F.I. (2015). Field Performance of Cultivars Nicola and Russet Burbank Micro and Minitubers. American Journal of Potato Research 92(2):298-302. https://doi.org/10.1007/s12230-0149421-9

Ranalli, P. (1997). Innovative propagation methods used 
in seed tuber multiplication systems. Potato Research 40(4):439-453. https://doi.org/10.1007/BF02358004

Ranalli, P., Bassi, F., Ruaro, G., Del Re, P., Di Candilo, M. and Mandolino. G. (1994). Microtuber and minituber production and field performance compared with normal tubers. Potato Research 37(4):383-391. https:// doi.org/10.1007/BF02358352

Teisson, C, and Alvard. D. (1999). In vitro production of potato microtubers in liquid medium using temporary immersion. Potato Research 42(3-4):499-504. https:// doi.org/10.1007/BF02358166

Venkatasalam E.P., Singh, B.P., Pandey, K.K., Latawa, J., Sharma, S., Sood, R. and Thakur V. (2012). Effect of carbon sources and explants on in vitro multiplication of potato. Potato Journal 39(2): 166-172. 